\title{
Georgiana Lungu-Badea, Idei şi metaidei traductive românești (secolele XVI-XXI), Ediţia a II-a, revăzută și adăugită, Editura Universităţii de Vest, Timișoara, 2015, 335 p.
}

\author{
Iulia Cosma* \\ Faculty of Letters, History and Theology, West University, Bd. Vasile Pârvan 4, 300223 Timişoara, Romania
}

In the academia, translation history imposed itself as a discipline starting with the second part of the $20^{\text {th }}$ century, along with the increasing interest in traductology and awareness of the need to study with appropriate scientific tools a secular practice which has contributed decisively to the emergence of literary works in vernacular languages and the creation of a common European culture. Historical research on translating can be identified in the works of literary language historians, literary historians or comparatists, even if the study of translational activity was not the target they were aiming at, the priority being rather to obtain valid arguments in supporting or contrasting interpretive hypotheses concerning phenomena of linguistic and literary influence. Interdisciplinary by excellence, the translation history has until recently been the Cinderella of the academic environment, being assigned an instrumental role. In this context, the emergence of the second and revised edition of Idei și metaidei traductive românești (secolele XVI-XXI) [Romanian Translational Ideas and Metatraslational Ideas $\left(16^{\text {th }}\right.$ $21^{\text {st }}$ centuries)] shows the consolidation of a process of self-determination for a discipline whose study can contribute to a better understanding of the phenomena of influence and linguistic, literary and cultural interference. This book by Georgiana Lungu-Badea is a translational research whose main purpose is to circumscribe and illustrate a complex phenomenon, with profound implications in the evolution of Romanian literary language and native literature, by establishing "an explicit connection between, on the one hand, early inductive translational theories from the $18^{\text {th }}$ and $19^{\text {th }}$ centuries, the borrowing of Western theoretical models (cultural, historical, etc.) and the deductive linguistic theories, and, on the other hand, the branches of the traductology: history, theory, practice theory, translation philosophy" (p. 5). The results find multiple applications, from the formation of future translators, to the implicit establishment of essential deontological reference points for researchers interested in studying the history of Romanian translation. As the author herself notes, we are dealing with a synthesis work (p. 5), the fruit of a long and intense research activity, of a mission assumed to clarify confusions of metalinguistic nature that can be seen in some translation studies in Romanian and the intention to revise some previous ideas from the perspective of the new approaches of the translational and traductological phenomenon: "we do not find it superfluous to recall that terms like traductiv or traducțional (Emil Iordache) and traductologic are not synonyms. [...] Between the terms that make up the aforementioned cleavage - terms derived from the dichotomy practice vs. (grosso modo) theory - there is the same difference that distinguishes the concepts of translation and traductology" (p. 5-6). Essential in this approach is the integration of the Romanian translational work and reflection into the European context. Thus, Georgiana Lungu-Badea gives us a tentative insight into translational and discursive practices with regard to translation, facilitating access to their understanding through recourse to the diachronic and intercultural dimension. Since the author is pointing to the mapping of a dynamic process, she favours an argumentative paradigm, considered indispensable for the identification and outline of the "guidelines of the pre-traductological thinking in the Romanian cultural space" (p. 14). The book index reflects the dialectical intent and permanent interest in the latest trends in translational research, providing the reader with a "comparative and contrastive-comparative" study of "inductive and empirical translational theories of the $19^{\text {th }}$ century that had a clear descriptive inclination and $[. .$.$] the linguistic deductive$

\footnotetext{
*Email address:cosmaiulia.m@gmail.com.
} 
ones (Latinism, Purism, Italianism), predominantly normative, the fundamental objective of which is to explain the logical rules on which concrete linguistic facts have been building the Romanian language." (p. 13). The impressive theoretical arsenal is not an artificial structure, but a flexible support that dynamically articulates the fruits of a rigorous and balanced interpretation effort.

The author has rearranged organization and denomination of some chapters, to make even clearer the existence, although in an incipient form, of some translation criticism and some attempts of translational theory integrable in the domain of traductology. Thus, the second chapter is titled Programe de traducere. Perspective pretraductologice românești [Translation programs. Romanian pretraductological perspectives] (p. 53-109), while chapters III$\mathrm{V}$ of the first edition which explore Kogălniceanu's position on the translations of his time, the role of dictionaries in the evolution of translational practice and implicitly in that of Romanian literary languages, and Simeon Marcovici's work now have become subchapters of the third one, III, Precepte de critică a traducerii și de lexicologie [Criticism precepts of translation and lexicology], as follows: III.1, Traducționita lui Mihail Kogălniceanu. Consecințe în plan literar [Mihail Kogalniceanu's aversion against translations. It's impact on the literature of that time] (p. 113-123), III.2, Traducere și dicționare. Rolul dicţionarelor în desăvîrșirea limbii și a traducerii [Translation and dictionaries. The role of dictionaries in perfecting language and translation] (p. 124139), and III.3, Miniportrete de traducători [Miniportraits of translators] (p. 140-163). The latter one deepens the third chapter of the first edition, also by including a synthesis of the translational activity of Dimitrie Cantemir (p. 155-156) and Costache Conachi (p. 157-158), as well as a panorama of the $19^{\text {th }}$ century motivations and translation strategies (p. 141-155). There are no differences in both the first chapter, I, Tălmăciri sau răstălmăciri? Inceputuri traductive românești (secolele al XV-lea al XIX-lea) [Interpretations or misinterpretations? Romanian Translational Beginnings $\left(15^{\text {th }}-19^{\text {th }}\right.$ centuries)] (p. 25-52), and the fourth one, IV, Perspective traductologice românești contemporane [Contemporary Romanian traductological perspectives] (p. 165-211). The Index of translators from the $19^{\text {th }}$ century (p. 218-235), obtained by processing data from Repertoriul traducătorilor români de limbă franceză, italiană spaniolă (secolele al XVIII-lea și al XIX-lea). Studii de istoria traducerii (I) [The repertoire of the Romanian translators from French, Italian Spanish (18 ${ }^{\text {th }}$ and $19^{\text {th }}$ centuries). Translation History Studies (I)], Editura Universității de Vest, 2006, coordinated by the author, along with the three annexes (p. 236-305), summing up essential texts for the understanding of the multiple factors that have exerted their influence on the translational activity in the Romanian space (I.1, Controverse referitoare la întîietatea scrierii cu alfabet latin față de scrierea cu alfabet chirilic [Controversies about the Latin lettering precedence over Cyrillic alphabet writing]; I.2, Despre rumân și român [About the terms rumân and român]; II, Cuvîntări despre traducere sec. XVI-XVII [Translation prefaces from $\left.16^{\text {th }}-17^{\text {th }} c.\right]$; III, Cuvîntări pretraductologice [Pretraductological prefaces]; III.1, Le Sage, Istoria lui Gil-Blas de Santillan [Le Sage, The History of Gil Blas of Santillane]; III.2, Rudolf de Jhering, Lupta pentru drept [Rudolf von Jhering, The Struggle for Law]; III.3, Amfilohie Hotiniul, "Prefața” la Gramatica de învățătură a fizicii [Amphiloch of Hotin, "Preface" to the Grammar of Learning Physics]; III.4, Fénelon, Intîmplările lui Telemah, ful lui Ulise. Traducere de G. Pleșoianu din limba franceză (pagina de titlu) [Fénelon, The Adventures of Telemachus, Son of Ulysses. Translation by G. Pleşoianu from French (title page)], 1831; III.5, A. Delavigne, Manualul de Filosofie. Traducere de A.T. Laurian (pagina de titlu) [A. Delavigne, Manual of Philosophy. Translation by A.T. Laurian (title page)]; III.6, Molière, Vicleniile lui Scapin [Molière, Scapin the Schemer]; III.7, Voltaire, Henriada [Voltaire, Henriade]; III.8, Marmontel, Velisarie. Scriere morală [Marmontel, Bélisaire. Moral writing]; III.9, Halima. T; III.10, Victor Hugo, Maria Tudor [Victor Hugo, Marie Tudor]) round off the diachronic perspective without making the volume cumbersome. One of the merits of the paper is precisely to highlight the usefulness of the translation history in the training of researchers in the field of humanistic studies. The motto of the present edition, "The work of the historian, as any work connected with the past, does not consist only in establishing the facts, but also in choosing some of them as more striking and more significant than others in the designation of relations between them" from Tzvetan Todorov's Hope and Memory, 
speaks about the positive assessment of the historian of translation, who has the difficult task of mediating between past and present, between his own culture and the source culture, without losing, as far as possible, balance and thus risk an overstepping of certain events or phenomena. Interdisciplinary formation, as the author implicitly suggests through the tools used in her research, proves to be essential in achieving this goal.

The importance of the volume Idei și metaide $i$ traductive românești (secolele XVI-XXI) [Romanian Translational Ideas and Metatraslational Ideas $\left(16^{\text {th }}\right.$ $21^{\text {st }}$ centuries)] can only be fully understood by reference to similar studies in other cultural spaces, such as those of Jean Delisle for Canada, Michel Ballard for France, Susan Basnett for England, or
Anthony Pym for Spain. Because, in addition to providing a specialist or someone specializing in the humanities, a synthetic and analytical treasure-trove designed to illuminate an essential period in the formation of our modern culture, Georgiana LunguBadea places the Romanian translational research in an international context, assuring it a well-deserved place in the history of the discipline by correlating the stages of the history of Romanian translation with the stages of the history of universal translation and demonstrating that in the Romanian cultural space "the incipient, inductive pre-transductological research (contextualization, conceptualization, recontextualization) is at the basis of the current research in traductology" (p. 13). 